Check for updates

Cite this: RSC Adv., 2017, 7, 55067

Received 14th September 2017 Accepted 20th November 2017

DOI: $10.1039 / \mathrm{c} 7 \mathrm{ra10210k}$

rsc.li/rsc-advances

\title{
Investigation of a halloysite-based fluorescence probe with a highly selective and sensitive "turn-on" response upon hydrogen peroxide $\uparrow$
}

\begin{abstract}
Jingwei Dong, Zhihang Zhao, Rui Liu, Hailei Zhang, (D) * Yonggang Wu and Xinwu Ba*
Inorganic halloysite nanotubes (HNTs) were modified with an organic fluorescein derivative (PA) to prepare HNTs-based hybrid fluorescence probe (HNTs-PA). Thermogravimetric analysis (TGA), Fourier transform infrared spectroscopy (FTIR), solid-state ${ }^{13} \mathrm{C}$ NMR spectroscopy, X-ray photoelectron spectroscopy (XPS), energy dispersive spectrum (EDS) and transmission electron microscopy (TEM) confirmed that PA was successfully grafted onto the lumen of HNTs to obtain HNTs-PA with a grafting degree of $6.0 \%$. The established $\mathrm{B}-\mathrm{C}$ bond endows a selective fluorescence response toward hydrogen peroxide $\left(\mathrm{H}_{2} \mathrm{O}_{2}\right)$ to HNTs-PA. The new hybrid probe exhibited a highly specific "turn-on" fluorescence response to $\mathrm{H}_{2} \mathrm{O}_{2}$ over other reactive oxygen species (ROS) and common ions owing to their chemoselective boronate-tophenol switch. The "turn-on" response could even be tracked when the additional amount of $\mathrm{H}_{2} \mathrm{O}_{2}$ was limited to $1 \times 10^{-7} \mathrm{~mol}$. Moreover, human lung cancer cells (A549 cells) were successfully stained and the staining intensity enhanced as time prolongs, which can be due to the overexpressed $\mathrm{H}_{2} \mathrm{O}_{2}$ of cancer cells. Thus, the as-prepared organic-inorganic hybrid fluorescence probe can have a broad range of applications for identification and diagnosis.
\end{abstract}

\section{Introduction}

Reactive oxygen species (ROS) often play important roles in cell signaling and are also regarded as biomarkers for some pathological changes in human beings. ${ }^{\mathbf{1 2}} \mathrm{H}_{2} \mathrm{O}_{2}$, one of the representative ROS, is often involved in inflammation, hemorrhage, tumor proliferation and so on. ${ }^{3-6}$ The accumulation of $\mathrm{H}_{2} \mathrm{O}_{2}$ can also destruct various cellular oxidants. Hence, it is important to trace the $\mathrm{H}_{2} \mathrm{O}_{2}$ at low levels in order to prevent and diagnose the abovementioned diseases, which presents the need for developing $\mathrm{H}_{2} \mathrm{O}_{2}$-sensitive fluorescent probes (Schemes 1 and 2).

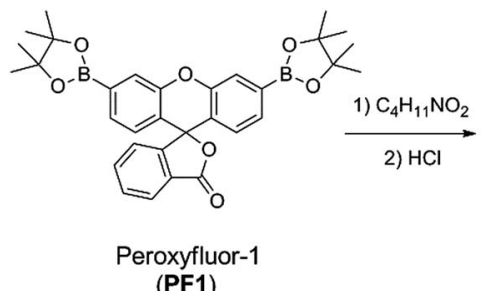

(PF1)

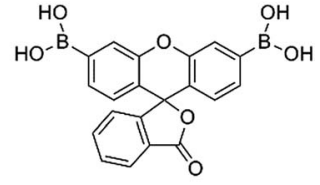

Boronic acid-contained fluorescein derivative (PA)
Scheme 1 Synthesis of boronic acid-contained fluorescein derivative (PA) by treating PF with diethanolamine and $\mathrm{HCl}$.

College of Chemistry \& Environmental Science, Hebei University, Baoding, Hebei Province071002, P. R. China.E-mail: haileipoly@126.com; wuyonggang@hbu.edu.cn $\dagger$ Electronic supplementary information (ESI) available. See DOI: 10.1039/c7ra10210k
Recent studies showed that the $\mathrm{H}_{2} \mathrm{O}_{2}$-triggered deprotection of arylboronates to phenols provided a reaction-based approach to the specific detection of $\mathrm{H}_{2} \mathrm{O}_{2}$, which results in the exploration of arylboronate-based fluorescent probes for $\mathrm{H}_{2} \mathrm{O}_{2}{ }^{3,7}$ Fluorescein and its derivates have attracted much attention primarily due to their high quantum yields, desirable photostability, and long emission wavelengths. Chang et al. reported a series of arylboronate-containing fluorescein derivatives. The $\mathrm{H}_{2} \mathrm{O}_{2}$-triggered deprotection of arylboronates to phenols can cause a dramatic increase in fluorescent intensity, where the "turn on" effect makes the synthesized fluorescein derivatives potential $\mathrm{H}_{2} \mathrm{O}_{2}$-sensitive fluorescent probes. ${ }^{3,7,8}$ However, the

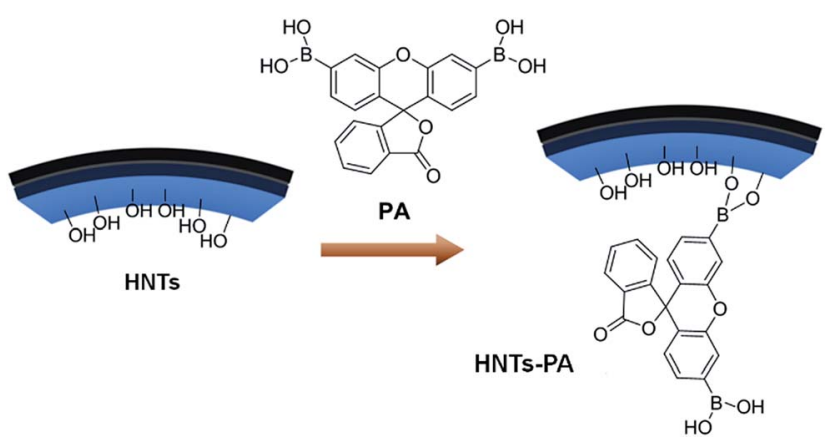

Scheme 2 Synthesis of HNTs-PA by treating HNTs with PA in anhydrous DMSO (We have demonstrated in the previous study that the overwhelming majority modification occurred in the inner surface of HNTs). ${ }^{42,43}$ 
undesirable solubility in aqueous system restricts their applicability to a broader range of applications.

Halloysite nanotubes (HNTs) are a type of natural tubular nanoparticles with a broad range of length to diameter ratios. ${ }^{9,10}$ The exterior and interior surfaces of HNTs are composed of siloxane ( $\mathrm{Si}-\mathrm{O}-\mathrm{Si})$ groups and gibbsite-like arrays of aluminol (Al-OH) groups, respectively, which results in a negatively charged outer surface and a positively charged inner lumen..$^{11,12}$ The peculiar composition allows selective functionalization at the inner or outer side, leading to the formation of a composite with a hierarchical nanostructure. ${ }^{13,14}$ Their attractive properties, including non-toxicity, harmlessness, high mechanical strength, and good biological adaptability, ${ }^{15-20}$ make HNTs find a variety of applications in fields such as electronics, catalysis, separation, and functional materials. ${ }^{21-25}$ Environment friendliness and biocompatible nature enable halloysite nanotubes (HNTs) to be a promising nanomaterial for developing organic/ inorganic composites in the biomedicine field. ${ }^{16,20,26-32}$ The surface modification of HNTs would create new types of smart functional materials. ${ }^{33-40}$ The selective modification methods have been extensively summarized in a latest review by our group. $^{41}$

In our previous studies, pyrenylboronic acid (PBA)-modified HNTs were prepared and the established Al-O-B linkage provided a "turn off" fluorescence response for $\mathrm{H}_{2} \mathrm{O}_{2}{ }^{42}$ In addition, a $\mathrm{H}_{2} \mathrm{O}_{2}$-responsive drug delivery system was also constructed using the established Al-O-B linkage. ${ }^{43}$ In this study, the fluorescein derivative bearing arylboronic acid was conjugated to the inner surface of HNTs using the previously reported method. Moreover, the established Al-O-B linkage can endow a "turn on" fluorescence response for $\mathrm{H}_{2} \mathrm{O}_{2}$ toward the fluorescein-modified HNTs. The good water-dispersity and biocompatibility properties of fluorescein-modified HNTs make them more suitable for imaging $\mathrm{H}_{2} \mathrm{O}_{2}$ signaling in living cells.

\section{Experimental}

\section{Materials}

HNTs were obtained from Guang Zhou Shinshi Metallurgy and Chemical Company Ltd (Guangzhou, China). Fluorescein was purchased from J\&K Chemical Technology. Dimethyl sulfoxide (DMSO) was dried and distilled from $\mathrm{CaH}_{2}$ under vacuum before use. Distilled water was used throughout the study. The reactions were monitored by thin layer chromatography (TLC) with silica gel 60 F254 (Merck $0.2 \mathrm{~mm}$ ). Column chromatography was carried out on silica gel (200-300 mesh). Peroxyfluor1 (PF1) was synthesized according to the literature. ${ }^{8}$

\section{Purification of HNTs}

HNTs were purified according to the method described in our previous study. ${ }^{44}$

\section{Synthesis of boronic acid-contained fluorescein derivative}

PF1 (940 mg, $1.7 \mathrm{mmol}$ ) and diethanolamine (400 mg, $3.8 \mathrm{mmol}$ ) were dissolved into an ether solution and then stirred at room temperature. After $50 \mathrm{~min}$, the precipitate was filtered, washed with ether, and dried in vacuum to afford a brown powder. Then, the obtained solid was treated with $0.1 \mathrm{M} \mathrm{HCl}$. After ultrasonication for about $30 \mathrm{~min}$ at room temperature, a yellow precipitate was obtained, which was centrifuged and washed with $0.1 \mathrm{M} \mathrm{HCl}$ to afford the product PA (435 mg, 66\%) (Scheme S1 $\dagger) .{ }^{1} \mathrm{H}$ NMR $\left(\left(\mathrm{CD}_{3}\right)_{2} \mathrm{SO}, 600 \mathrm{MHz}, \mathrm{ppm}\right): \delta 8.34$ $(\mathrm{s}, 1 \mathrm{H}), 8.05(\mathrm{t}, J=8.0 \mathrm{~Hz}, 1 \mathrm{H}), 7.78(\mathrm{~s}, 2 \mathrm{H}), 7.76(\mathrm{~d}, J=7.4 \mathrm{~Hz}$, $1 \mathrm{H}), 7.75(\mathrm{~d}, J=7.4 \mathrm{~Hz}, 1 \mathrm{H}), 7.50(\mathrm{t}, J=8.0 \mathrm{~Hz}, 2 \mathrm{H}), 7.28(\mathrm{t}, J=$ $7.6 \mathrm{~Hz}, 1 \mathrm{H}), 6.80(\mathrm{~d}, J=7.8 \mathrm{~Hz}, 2 \mathrm{H}) .{ }^{13} \mathrm{C} \mathrm{NMR}\left(\left(\mathrm{CD}_{3}\right)_{2} \mathrm{SO}, 150\right.$ MHz, ppm): $\delta 168.7,152.9,149.9,135.8,129.3,126.6,125.1$, 124.9, 123.9, 122.4, 119.9, 81.5. FTIR (KBr): 3622, 3525, 3025, $2921,1410 \mathrm{~cm}^{-1}$. Elemental analysis: calcd (\%) for $\mathrm{C}_{20} \mathrm{H}_{14} \mathrm{~B}_{2} \mathrm{O}_{7}$ : C 61.92, H 3.64; found: C 61.81, H 3.69.

\section{Preparation of HNTs-PA}

A mixture of purified HNTs $(120 \mathrm{mg})$ and PA (40 mg) in anhydrous DMSO was carefully degassed. The system was heated at $80{ }^{\circ} \mathrm{C}$ for $12 \mathrm{~h}$ under stirring in nitrogen. The mixture was cooled to room temperature and washed by diethyl ether. The residue was collected by centrifugation. After vacuum-drying, the HNTs-PA was obtained as a faint grey solid.

\section{Generation of reactive oxygen species (ROS) and common ions}

Nitric oxide ( $\mathrm{NO}^{\circ}$ ) was generated from sodium nitroferricyanide $\left(\mathrm{Na}_{2} \mathrm{Fe}(\mathrm{CN})_{5} \mathrm{NO}\right) .{ }^{45} \mathrm{H}_{2} \mathrm{O}_{2}$, and $\mathrm{ClO}^{-}$were delivered from $30 \%$ $\mathrm{H}_{2} \mathrm{O}_{2}$, and $5 \% \mathrm{NaClO}$ aqueous solutions, respectively. Metal ions $\left(\mathrm{Cu}^{2+}, \mathrm{Fe}^{3+}, \mathrm{Fe}^{2+}, \mathrm{Mg}^{2+}, \mathrm{Na}^{+}, \mathrm{Zn}^{2+}, \mathrm{K}^{+}, \mathrm{Ca}^{2+}\right)$ and anions $\left(\mathrm{SO}_{4}{ }^{2-}, \mathrm{H}_{2} \mathrm{PO}_{4}{ }^{-}, \mathrm{S}_{2} \mathrm{O}_{3}{ }^{2-}, \mathrm{NO}_{3}{ }^{-}, \mathrm{CO}_{3}{ }^{2-}, \mathrm{Cl}^{-}\right)$were derived from $\mathrm{CuSO}_{4}, \mathrm{FeCl}_{3}, \mathrm{FeCl}_{2}, \mathrm{MgSO}_{4}, \mathrm{NaCl}, \mathrm{ZnCl}_{2}, \mathrm{KCl}, \mathrm{CaCl}_{2}, \mathrm{Na}_{2} \mathrm{SO}_{4}$, $\mathrm{NaH}_{2} \mathrm{PO}_{4}, \mathrm{Na}_{2} \mathrm{~S}_{2} \mathrm{O}_{3}, \mathrm{NaNO}_{3}, \mathrm{Na}_{2} \mathrm{CO}_{3}, \mathrm{NaCl}$, respectively.

\section{Cell cultures}

Human lung cancer cells (A549 cells) and Hela cells were cultured in Dulbecco's modified Eagles medium (DMEM, Beijing North TZ-Biotech Develop, Co. Ltd.) with $10 \%$ fetal bovine serum and $100 \mathrm{U} \mathrm{mL}^{-1}$ of $1 \%$ antibiotics (penicillin/ streptomycin). A549 cells were placed on a confocal dish and the number of cells on each confocal dish was about $5.0 \times 10^{3}$. Then the cells were maintained at $37{ }^{\circ} \mathrm{C}$ for $12 \mathrm{~h}$ in a $100 \%$ humidified atmosphere containing $5 \% \mathrm{CO}_{2}$ for further use.

\section{MTT assay}

A549 cells or Hela cells were seeded in a 96-well plate at a density of $4 \times 10^{3}$ per well. The cells were provided by the Chinese Academy of Medical Sciences, Peking Union Medical College. Accurately weighed HNTs-PA probes were dissolved in phosphate buffered saline (PBS) to achieve mother liquors. Following this, the cells were further incubated in media containing various concentrations diluted from the mother liquors. The plates were maintained at $37{ }^{\circ} \mathrm{C}$ in a $5 \% \mathrm{CO}_{2} / 95 \%$ air incubator for $24 \mathrm{~h}$. After $24 \mathrm{~h}$, the medium was removed and washed with PBS. MTT solution $\left(0.5 \mathrm{mg} \mathrm{mL}^{-1}, 100 \mu \mathrm{L}\right)$ was then added to each well. After $4 \mathrm{~h}$, the remaining MTT solution was removed and $100 \mu \mathrm{L}$ of DMSO was added to each well to dissolve 
the formazan crystals. Absorbance was set at $520 \mathrm{~nm}$ by a Triturus microplate reader. Wells containing no samples were used as blank control. The cell viability (\%) was calculated as the ratio of the number of surviving cells in the test samples to the control groups.

\section{Cell imaging}

Cells were grown in Minimum Essential Medium Eagle (MEM medium, Sigma) in a watch glass bottom poly-D-lysine coated Petri-dish for at least $24 \mathrm{~h}$ to enable adherence to the bottom. Accurately weighed amounts of HNTs-PA suspension or Mitotracker Red were added to the medium at $37{ }^{\circ} \mathrm{C}$ in $5 \% \mathrm{CO}_{2}$. The cells were maintained in an incubator for another $30 \mathrm{~min}$ to achieve a sample loaded MEM medium. Then, the cells were washed three times with DPBS buffer to remove the samples that were not taken up into the cells. Finally, DMEM was added. A Hitachi F-4500 spectrofluorometer (Tokyo, Japan) equipped with a xenon lamp was used to obtain the fluorescence spectra. All experimental parameters (the laser intensity, exposure time, objective lens) were stationary when the different fluorescence images were captured. The excitation wavelength was fixed at $488 \mathrm{~nm}$ and fluorescent signals were collected from 500 to $600 \mathrm{~nm}$.

\section{Characterizations}

Microwave reactions were performed using a Discover (PE-CEM) reactor. UV-visible absorption spectra were obtained on a Shimadzu UV-visible spectrometer model UV-2550. Fluorescence spectra were recorded on a Shimadzu RF-5301PC. TGA was performed on Perkin-Elmer Pyris 6 under a nitrogen flow. Accurately weighed amounts of samples were heated at a scanning rate of $10{ }^{\circ} \mathrm{C} \min ^{-1}$ from $40{ }^{\circ} \mathrm{C}$ to $800{ }^{\circ} \mathrm{C}$. The morphological characterizations were performed using a Tecnai $\mathrm{G}^{2} \mathrm{~F} 20$ S-TWIN transmission electron microscope (TEM) with an accelerating voltage of $200 \mathrm{kV}$. FTIR spectra were recorded in the region of $400-4000 \mathrm{~cm}^{-1}$ for each sample on a Varian-640 spectrophotometer. The samples were previously grounded and mixed thoroughly with $\mathrm{KBr}$. The spectrum for each sample was obtained by averaging 32 scans over the selected wave number range. ${ }^{13} \mathrm{C}$ solid-state NMR spectra were recorded on a Bruker Advance III spectrometer. X-ray photoelectron spectroscopy (XPS) was carried out on a Thermo Scientific ESCALab 250Xi using $200 \mathrm{~W}$ monochromated $\mathrm{Al} \mathrm{K} \alpha$ radiation. The $500 \mu \mathrm{m}$ X-ray spot was used for XPS analysis. The base pressure in the analysis chamber was about $3 \times 10^{-10} \mathrm{mbar}$. Typically the hydrocarbon $\mathrm{C} 1 \mathrm{~s}$ line at $284.8 \mathrm{eV}$ from adventitious carbon was used for energy referencing. The energy dispersive spectrum (EDS) was determined by a Hitachi S-4800 scanning electron microscope.

\section{Results and discussion}

Previous studies have demonstrated that arylboronic acid can react with the hydroxyls spread on the surface of HNTs. ${ }^{\mathbf{4 2 , 4 3}}$ In this study, a fluorescein derivative bearing an arylboronic acid group was synthesized and then bound to the interior surface of
HNTs according to the above-mentioned method. The obtained nanocomposite (HNTs-PA) showed desirable dispersibility in aqueous solution. The differences between HNTs-PA and HNTs were revealed by FTIR, XPS and solid-state ${ }^{13} \mathrm{C}$ NMR.

Fig. 1 shows the solid-state ${ }^{13} \mathrm{C}$ NMR spectra of HNTs and HNTs-PA. HNTs show no visible resonance in the region from 0 to 200 ppm, implying the absence of carbon units in HNTs. Moreover, remarkable resonances ranging from 180 to $40 \mathrm{ppm}$ can be clearly observed in the solid-state ${ }^{13} \mathrm{C}$ NMR spectrum of HNTs-PA. The peaks at 170.7 and 83.8 are attributed to the carbon in $-\mathrm{C}=\mathrm{O}$ and the quaternary carbon in the PA units. The resources from 157.1 to 116.9 can be assigned to the aromatic carbons in the PA units. The remarkable difference in the ${ }^{13} \mathrm{C}$ NMR spectra between HNTs and HNTs-PA indicated the presence of fluorescein groups in HNTs-PA.

The FTIR spectra of HNTs and HNTs-PA are shown in Fig. 2. In the spectrum of HNTs, two distinct peaks located at 3696 and $3622 \mathrm{~cm}^{-1}$ are attributed to the inner hydroxyl groups lying between the tetrahedral and octahedral sheets and the surface hydroxyl groups in the lumen of the nanotubes, respectively. The band at $1034 \mathrm{~cm}^{-1}$ is assigned to the stretching vibration of $\mathrm{Si}-\mathrm{O}-\mathrm{Si}$. The FTIR spectrum matches well with the composition of HNTs.

As for HNTs-PA, the distinct band corresponding to the surface hydroxyl groups in the lumen at $3696 \mathrm{~cm}^{-1}$ displays a significant decrease, suggesting the consumption of surface hydroxyl groups in lumen during the modification. Simultaneously, some new peaks at 3525, 3025, 2921, 1765 and $1410 \mathrm{~cm}^{-1}$ can be clearly observed, which can be attributed to the $-\mathrm{OH}$ stretching, Ar- $\mathrm{H}$ group, $\mathrm{C}-\mathrm{H}$ bond, $\mathrm{C}=\mathrm{O}$ bond and aromatic ring group, respectively. The FTIR results indicate that the fluorescein derivative was grafted on the inner surface of HNTs via the condensation reaction.

The quantity of the fluorescein derivative grafted to the nanotube was calculated to be $6.0 \mathrm{wt} \%$ by thermogravimetric analysis (TGA, Fig. 3). The XPS spectra are presented in the ESI. $\uparrow$ Original HNTs and HNTs-PA all show the presence of aluminium ( $\mathrm{Al} 2 \mathrm{~s}$ and $\mathrm{Al} 2 \mathrm{p}$ ) and silicon ( $\mathrm{Si} 2 \mathrm{p}$ ), in accordance

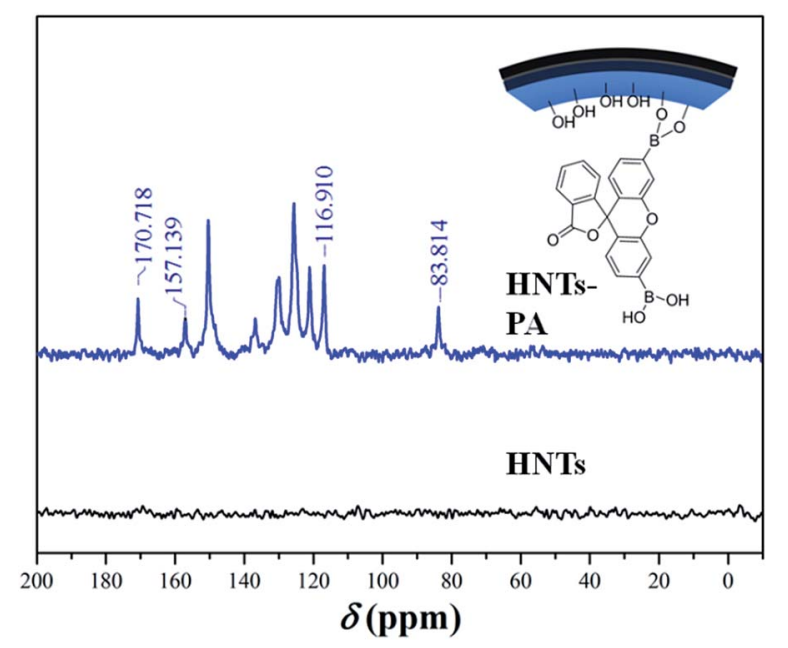

Fig. 1 Solid-state ${ }^{13} \mathrm{C}$ NMR spectra of HNTs and HNTs-PA. 


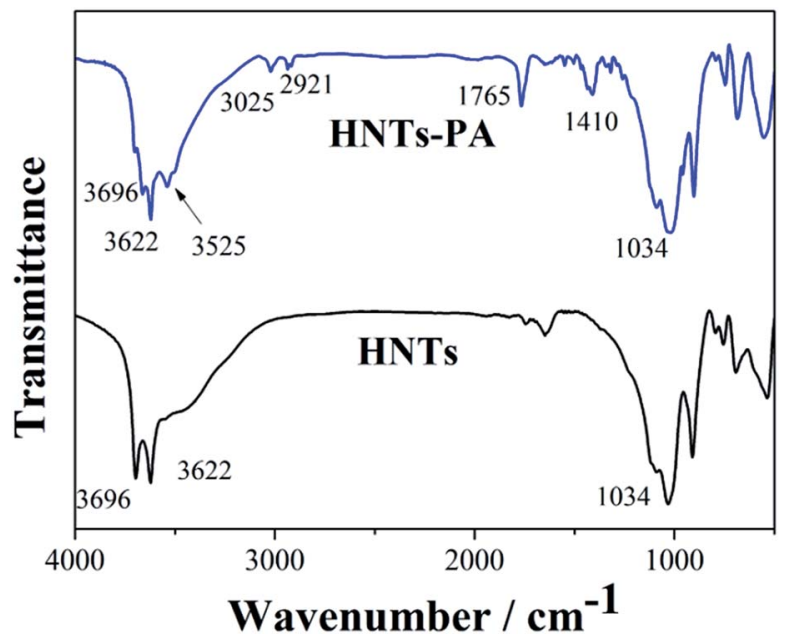

Fig. 2 FTIR spectra of HNTs and HNTs-PA.

with the composition of alumino-silicate clay. The newly emerged weak peak of B 1s at $191.5 \mathrm{eV}$ supports the successful modifications, where the atomic percentage of boron on the surface of HNTs-PA is calculated to be $0.6 \%$, which is much less than the grafting degree calculated by TGA results. Generally, the wall thickness of HNTs exceeds the penetration depth of XPS $(10 \mathrm{~nm}){ }^{14}$ Hence, it is difficult to disclose the chemical composition of the inner lumen surface. The weak signal of B 1s in the XPS spectrum of HNTs-PA can be attributed to the fractions grafted on the opening of the tubes. The XPS results indicate that a vast majority of the fluorescein units were grafted on the HNTs lumen, which matches well with our previous findings and the FTIR results. The chemical composition of HNTs-PA was also investigated by EDS (shown in ESI $\dagger$ ). The atomic\% of $\mathrm{O}, \mathrm{Al}$ and $\mathrm{Si}$ were calculated as $38.17 \%, 22.37 \%$ and $24.12 \%$, respectively. The results of the presence of $\mathrm{O}, \mathrm{Al}$ and $\mathrm{Si}$ are in accordance with the composition of alumino-silicate clay. The presence of carbon units (atomic $\%=11.25 \%$ ) revealed that

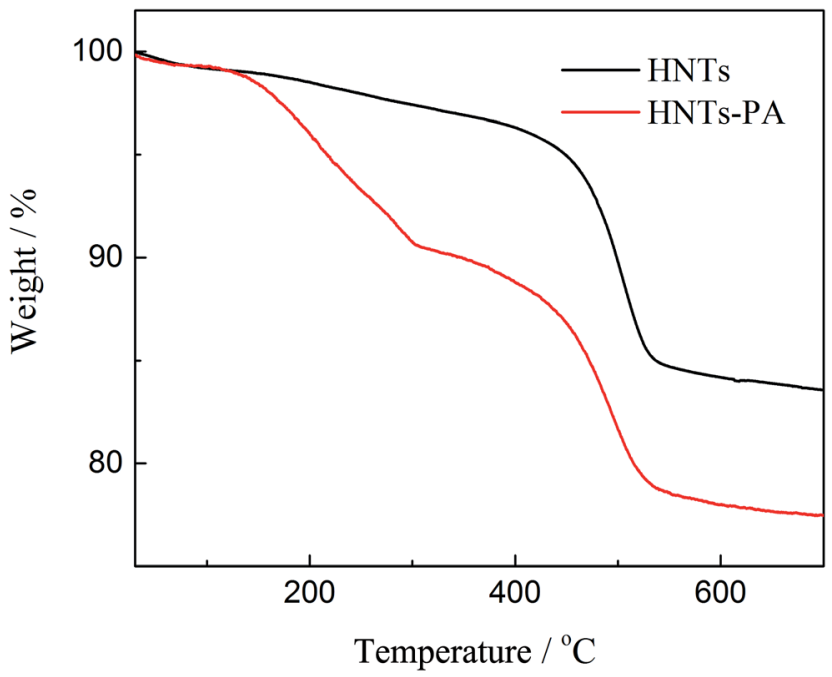

Fig. 3 TGA curves of HNTs and HNTs-PA. the fluorescein groups were immobilized onto the HNTs, which matched well with the solid-state ${ }^{13} \mathrm{C}$ NMR results.

The TEM images of original HNTs and HNTs-PA are shown in Fig. 4. Fig. 4A shows that the original HNTs possess a cylindrical shape and contain a transparent central area that runs longitudinally along the cylinder. The nanotubular particles are hollow and open ended, with a length of $0.5-1.0 \mu \mathrm{m}$, an inner diameter of $20-30 \mathrm{~nm}$ and an outer diameter of $40-60 \mathrm{~nm}$, which can be untaken or phagocytized in cell cultures.

After modification, the tubes retain their smooth outermost surface. Moreover, the lumen is almost completely filled, suggesting that the fluorescein derivative was successfully grafted onto alumina at the tube lumen and did not bind the outer siloxane surface of the tube. The overall morphologies of these nanotubes were similar to those of the original nanotube, indicating that the nanotubes underwent slight damage during the grafting reaction.

The established $\mathrm{B}-\mathrm{C}$ link in the modified HNTs can be degraded into B-OH and Ar-OH in the presence of $\mathrm{H}_{2} \mathrm{O}_{2}$ as well as the $\mathrm{B}-\mathrm{C}$ link in the fluorescein derivative. The quantum yield $\left(\Phi_{\mathrm{f}}\right)$ of HNTs-PA was calculated as $c a$. 0.01 , with quinine sulfate ( $\Phi_{\mathrm{f}}=0.55$ in $0.05 \mathrm{M} \mathrm{H}_{2} \mathrm{SO}_{4}$ ) as the reference standard. Moreover, the degradation product, fluorescein, possesses a significantly higher fluorescence quantum yield $\left(\Phi_{\mathrm{f}}=0.94\right.$ in $0.1 \mathrm{M}$ $\mathrm{NaOH}^{3}$ ) than modified HNTs and fluorescein derivative bearing arylboronic acid groups. Therefore, the degradation from HNTs-PA to fluorescein can dramatically increase the

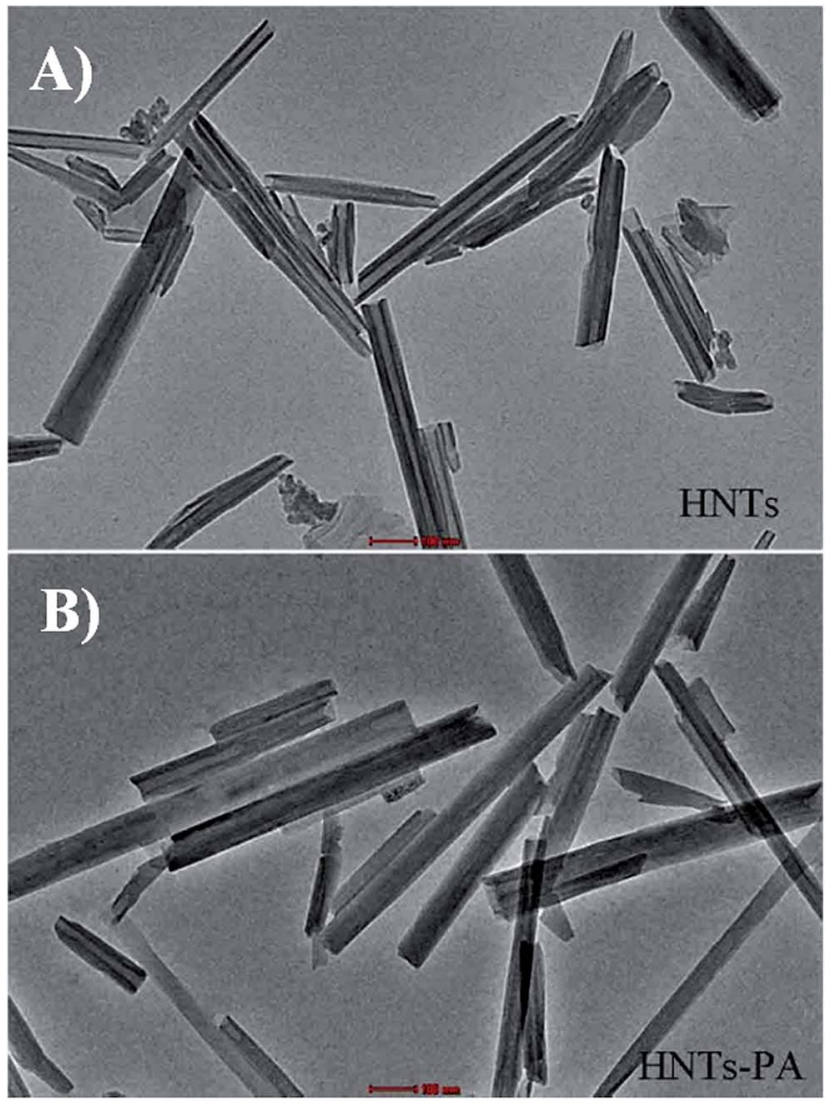

Fig. 4 TEM images of HNTs and HNTs-PA 
fluorescence intensity, which can be called a "turn-on" response. The "turn-on" response in fluorescence intensity toward $\mathrm{H}_{2} \mathrm{O}_{2}$ can endow a $\mathrm{H}_{2} \mathrm{O}_{2}$-detecting ability of modified HNTs.

Fig. 5 shows the fluorescence responses of HNTs-PA to $\mathrm{H}_{2} \mathrm{O}_{2}$. When $5 \times 10^{-6} \mathrm{~mol} \mathrm{H}_{2} \mathrm{O}_{2}$ was added, the HNTs-PA aqueous solution displayed a drastic increase in fluorescence intensity in $30 \mathrm{~min}$. A 50-fold difference in fluorescence intensity can even be detected when the amount of added $\mathrm{H}_{2} \mathrm{O}_{2}$ decreased to $1 \times$ $10^{-7}$ mol (shown in ESI $\dagger$ ), where the concentration of $\mathrm{H}_{2} \mathrm{O}_{2}$ is $5 \times 10^{-5}$ M. Previously, we developed a HNTs-based $\mathrm{H}_{2} \mathrm{O}_{2}$ sensitive fluorescence probe, for which the fluorescence response could not be tracked when the concentration of $\mathrm{H}_{2} \mathrm{O}_{2}$ decreased to $5 \times 10^{-5} \mathrm{M}$. Therefore, the HNTs-PA shows a prominent advantage as compared to the previous probe. ${ }^{42}$ Owing to their chemoselective boronate switch, HNTs-PA probes retain highly specific responses to $\mathrm{H}_{2} \mathrm{O}_{2}$. Other groups did not show the "turn-on" fluorescence when treated with other ROS agents, including $\mathrm{NO}^{\circ}$ and $\mathrm{ClO}^{-}$(shown in the $\mathrm{ESI}^{\dagger}$ ). The fluorescence intensity of HNTs-PA was found to be almost unaffected by the addition of metal ions $\left(\mathrm{Cu}^{2+}, \mathrm{Fe}^{3+}, \mathrm{Fe}^{2+}, \mathrm{Mg}^{2+}\right.$, $\left.\mathrm{Na}^{+}, \mathrm{Zn}^{2+}, \mathrm{K}^{+}, \mathrm{Ca}^{2+}\right)$ and anions $\left(\mathrm{SO}_{4}{ }^{2-}, \mathrm{H}_{2} \mathrm{PO}_{4}{ }^{-}, \mathrm{S}_{2} \mathrm{O}_{3}{ }^{2-}, \mathrm{NO}_{3}{ }^{-}\right.$, $\mathrm{CO}_{3}{ }^{2-}, \mathrm{Cl}^{-}$). Such favorable performances make the modified HNTs a desirable $\mathrm{H}_{2} \mathrm{O}_{2}$-responsive fluorescence probe in vivo.

To evaluate the cytotoxicity of the modified HNTs, the growth inhibitory activity against A549 cells was calculated based on a MTT assay. The concentration expressed in the Fig. 6 represents the concentration of HNTs-PA in aqueous suspension. The results indicate that HNTs-PA shows low cytotoxicity (over $80 \%$ cell viability) within 24 h of incubation time, in which the concentration of HNTs-PA ranges from 0.05 to $1.0 \mathrm{mg} \mathrm{mL}{ }^{-1}$, which makes the modified HNYs desirable biological materials at cellular levels. In addition, the cytotoxicity of HNTs-PA was also evaluated using Hela cells, where the $\mathrm{IC}_{50}$ was calculated to be $1.11 \mathrm{mg} \mathrm{mL}^{-1}$.
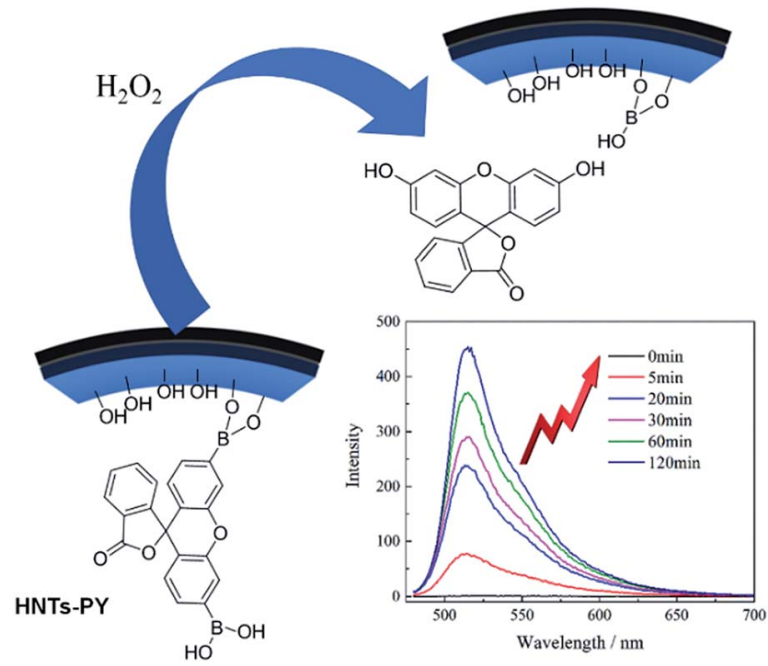

Fig. 5 Response mechanism of HNTs-PA to hydrogen peroxide and the fluorescence spectra of HNTs-PA aqueous suspension $\left([c]=0.1 \mathrm{mg} \mathrm{mL}^{-1}\right)$ after addition of $5 \times 10^{-6} \mathrm{~mol} \mathrm{H}_{2} \mathrm{O}_{2}\left(\left[\mathrm{H}_{2} \mathrm{O}_{2}\right]=2.5 \times\right.$ $\left.10^{-3} \mathrm{M}\right)$.

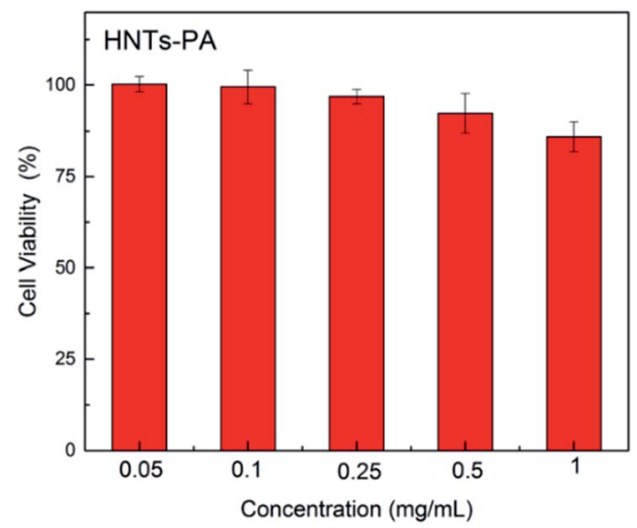

Fig. 6 Cell viability of A549 at different concentrations of HNTs-PA.

It is well-known that the overexpression of $\mathrm{H}_{2} \mathrm{O}_{2}$ usually occurs around the tumor cells. We next assessed the ability of HNTs-PA to stain within human lung cancer cells (A549 cells). A549 cells were incubated with $0.5 \mathrm{mg} \mathrm{mL}^{-1}$ HNTs-PA for 1, 2, 4, 8 and $12 \mathrm{~h}$ at $37^{\circ} \mathrm{C}$ (shown in Fig. 7). The excitation wavelength was fixed at $488 \mathrm{~nm}$ and fluorescent signals were collected from 500 to $600 \mathrm{~nm}$. A reference test was also made by incubating A549 cells with Mitotracker Red, which is a commercially available fluorescent dye for cell imaging. The images indicated that the cells can be stained under the endogenous levels of

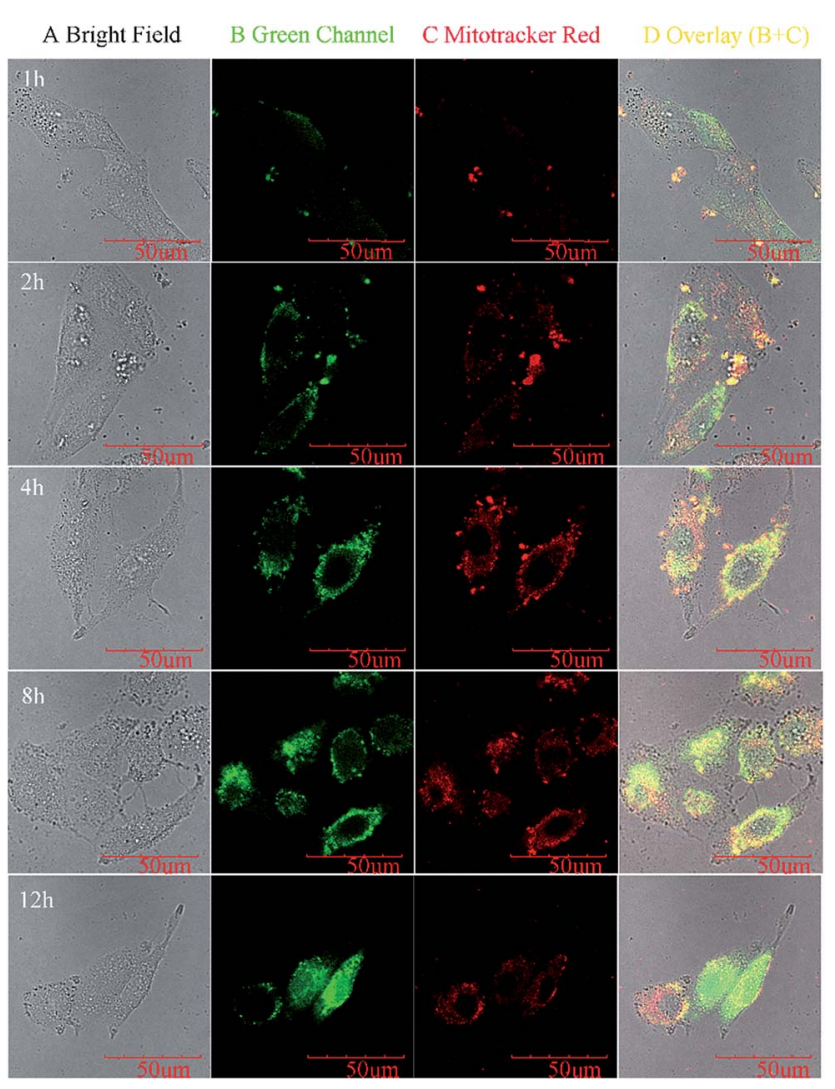

Fig. 7 Confocal fluorescence images of living A549 cells under same condition with HNTs-PA (Green Channel) or Mitotracker Red for 1, 2, 4, 8 and $12 \mathrm{~h}$. 
$\mathrm{H}_{2} \mathrm{O}_{2}$ derived from the cancer cells, where the fluorescence intensity increased as time extends. Moreover, the fluorescence intensity of the cells treated by Mitotracker Red remained almost unchanged after $4 \mathrm{~h}$. The difference can be due to the fact that the fluorescein unit gradually released from the lumen as the $\mathrm{B}-\mathrm{C}$ bond broke into $\mathrm{B}-\mathrm{OH}$ and $\mathrm{Ar}-\mathrm{OH}$ in the presence of $\mathrm{H}_{2} \mathrm{O}_{2}$, which corresponds to the "turn on" response of HNTs-PA on $\mathrm{H}_{2} \mathrm{O}_{2}$. We also assessed the ability of HNTs-PA to stain within Hela cells. The results indicated that the cells can also be stained and the fluorescence intensity increased as time extends, which can also be due to the endogenous levels of $\mathrm{H}_{2} \mathrm{O}_{2}$. The $\mathrm{H}_{2} \mathrm{O}_{2}$ concentration in mammals commonly ranges from $1 \mathrm{nM}$ to $0.5 \mu \mathrm{M}$ and is usually overexpressed in cancer cells and tissues. Sometimes the $\mathrm{H}_{2} \mathrm{O}_{2}$ concentration in cancer cells can exceed $50 \mu \mathrm{M}^{46}$ The $\mathrm{H}_{2} \mathrm{O}_{2}$ in A549 cells and Hela cells should also be in this range, implying the HNTs-PA is capable of detecting the endogenic $\mathrm{H}_{2} \mathrm{O}_{2}$ at this level.

\section{Conclusions}

In summary, we have described the design and synthesis of a fluorescent probe HNTs-PA, which can be used for the detection of $\mathrm{H}_{2} \mathrm{O}_{2}$. The nanocomposite showed regular morphology and desirable dispersibility in aqueous solution. The established B-C linkage provides a highly specific $\mathrm{H}_{2} \mathrm{O}_{2}$ sensitivity to HNTs-PA; as a result, the probe exhibits a highly specific "turn-on" fluorescence response for hyperoxide. Moreover, HNTs-PA was found to be capable to monitor $\mathrm{H}_{2} \mathrm{O}_{2}$ derived from A549 cells under physiological conditions. The prepared HNTs-based fluorescent probe can open new applications in the detection of cancer cells and thus serve as a practical tool for cancer diagnosis.

\section{Conflicts of interest}

The authors declare that they have no conflict of interest.

\section{Acknowledgements}

This work was supported by the National Natural Science Foundation of China (Grant No. 21474026 and 21274037), and the Outstanding Doctoral Cultivation Project of Hebei University (YB201501).

\section{Notes and references}

1 H. Sies, J. Biol. Chem., 2014, 289, 8735-8741.

2 S. Rhee, Science, 2006, 312, 1882-1883.

3 B. Dickinson, C. Huynh and C. Chang, J. Am. Chem. Soc., 2010, 132, 5906-5915.

4 N. Houstis, E. D. Rosen and E. S. Lander, Nature, 2006, 440, 944-948.

5 T. Finkel, M. Serrano and M. A. Blasco, Nature, 2007, 448, 767-774.

6 C. Liu, W. Chen, Z. Qing, J. Zheng, Y. Xiao, S. Yang, L. Wang, Y. Li and R. Yang, Anal. Chem., 2016, 88, 3998-4003.
7 E. Miller, O. Tulyanthan, E. Isacoff and C. Chang, Nat. Chem. Biol., 2007, 3, 263-267.

8 M. C. Chang, A. Pralle, E. Y. Isacoff and C. J. Chang, J. Am. Chem. Soc., 2004, 126, 15392-15393.

9 Y. Lvov, W. Wang, L. Zhang and R. Fakhrullin, Adv. Mater., 2016, 28, 1227-1250.

10 Y. Lvov, A. Aerov and R. Fakhrullin, Adv. Colloid Interface Sci., 2014, 207, 189-198.

11 Y. Lvov, D. Shchukin, H. Mohwald and R. Price, ACS Nano, 2008, 2, 814-820.

12 L. Guimaraes, A. Enyashin, G. Seifert and H. Duarte, J. Phys. Chem. C, 2010, 114, 11358-11363.

13 W. Yah, A. Takahara and Y. Lvov, J. Am. Chem. Soc., 2012, 134, 1853-1859.

14 W. Yah, H. Xu, H. Soejima, W. Ma, Y. Lvov and A. Takahara, J. Am. Chem. Soc., 2012, 134, 12134-12137.

15 V. Vergaro, E. Abdullayev and Y. M. Lvov, Biomacromolecules, 2010, 11, 820-826.

16 C. Chao, J. Liu, J. Wang, Y. Zhang, B. Zhang, Y. Zhang, X. Xiang and R. Chen, ACS Appl. Mater. Interfaces, 2013, 5, 10559-10564.

17 Z. Yi, Y. Xie, A. Tang, Y. Zhou, O. Jing and H. Yang, Ind. Eng. Chem. Res., 2014, 53, 5507-5514.

18 G. Cavallaro, D. I. Donato, G. Lazzara and S. Milioto, J. Phys. Chem. C, 2011, 115, 20491-20498.

19 G. Cavallaro, G. Lazzara and S. Milioto, J. Phys. Chem. C, 2012, 116, 21932-21938.

20 M. Liu, R. He, J. Yang, W. Zhao and C. Zhou, ACS Appl. Mater. Interfaces, 2016, 8, 7709-7719.

21 S. R. Levis and P. B. Deasy, Int. J. Pharm., 2002, 243, 125-134.

22 Y. W. On, T. Atsushi and Y. M. Lvov, J. Am. Chem. Soc., 2012, 134, 1853-1859.

23 D. G. Shchukin, G. B. Sukhorukov, R. R. Price and Y. M. Lvov, Small, 2005, 1, 510-513.

24 E. Tierrablanca, J. Romero-García, P. Roman and R. CruzSilva, Appl. Catal., A, 2010, 381, 267-273.

25 E. Abdullayev, V. Abbasov, A. Tursunbayeva, V. Portnov, H. Ibrahimov, G. Mukhtarova and Y. Lvov, ACS Appl. Mater. Interfaces, 2013, 5, 4464-4471.

26 L. Liu, Y. Wan, Y. Xie, R. Zhai, B. Zhang and J. Liu, Chem. Eng. J., 2012, 187, 210-216.

27 D. Fix, D. V. Andreeva, Y. M. Lvov, D. G. Shchukin and H. Möhwald, Adv. Funct. Mater., 2009, 19, 1720-1727.

28 R. Zhai, B. Zhang, L. Liu, Y. Xie, H. Zhang and J. Liu, Catal. Commun., 2010, 12, 259-263.

29 M. J. Mitchell, C. A. Castellanos and M. R. King, Biomaterials, 2015, 56, 179-186.

30 V. Vergaro, E. Abdullayev, Y. Lvov, A. Zeitoun, R. Cingolani, R. Rinaldi and S. Leporatti, Biomacromolecules, 2010, 11, 820-826.

31 G. Sandri, C. Aguzzi, S. Rossi, M. C. Bonferoni, G. Bruni, C. Boselli, A. I. Cornaglia, F. Riva, C. Viseras and C. Caramella, Acta Biomater., 2017, 55, 216-224.

32 E. A. Naumenko, I. D. Guryanov, R. Yendluri, Y. M. Lvov and R. F. Fakhrullin, Nanoscale, 2016, 8, 7257-7271.

33 V. Vergaro, Y. M. Lvov and S. Leporatti, Macromol. Biosci., 2012, 12, 1265-1271. 
34 M. T. Viseras, C. Aguzzi, P. Cerezo, C. Viseras and C. Valenzuela, Microporous Mesoporous Mater., 2008, 108, 112-116.

35 M. Massaro, G. Lazzara, S. Milioto, R. Noto and S. Riela, J. Mater. Chem. B, 2017, 5, 2867-2882.

36 Y. Lvov, M. Devilliers and R. Fakhrullin, Expert Opin. Drug Delivery, 2016, 13, 977-986.

37 A. A. Kadam, J. Jang and D. S. Lee, ACS Appl. Mater. Interfaces, 2017, 9, 15492-15501.

38 M. Liu, Y. Chang, J. Yang, Y. You, R. He, T. Chen and C. Zhou, J. Mater. Chem. B, 2016, 4, 2253-2263.

39 S. Riela, M. Massaro, C. Colletti, A. Bommarito, C. Giordano, S. Milioto, R. Noto, P. Poma and G. Lazzara, Int. J. Pharm., 2014, 475, 613-623.
40 M. Massaro, R. Amorati, G. Cavallaro, S. Guernelli, G. Lazzara, S. Milioto, R. Noto, P. Poma and S. Riela, Colloids Surf., B, 2016, 140, 505-513.

41 H. Zhang, Nanotechnol. Rev., 2017, 6, 573-581.

42 H. Zhang, T. Ren, Y. Ji, L. Han, Y. Wu, H. Song, L. Bai and X. Ba, ACS Appl. Mater. Interfaces, 2015, 7, 23805-23811.

43 F. Liu, L. Bai, H. Zhang, H. Song, L. Hu, Y. Wu and X. Ba, ACS Appl. Mater. Interfaces, 2017, 9, 31626-31633.

44 Z. Luo, H. Song, X. Feng, M. Run, H. Cui, L. Wu, J. Gao and Z. Wang, Langmuir, 2013, 29, 12358-12366.

45 L. Gai, J. Mack, H. Liu, Z. Xu, H. Lu and Z. Li, Sens. Actuators, $B, 2013,182,1-6$.

46 M. Asif, H. Liu, A. Aziz, H. Wang, Z. Wang, M. Ajmal, F. Xiao and H. Liu, Biosens. Bioelectron., 2017, 97, 352-359. 